\title{
The Effects of Russia's Great Power Eminence and Sovereign State Perception on the Balkans
}

\author{
Murat Yorulmaz ${ }^{\mathrm{a}, \mathrm{b}}$
}

\begin{abstract}
At the end of the $20^{\text {th }}$ century, all states over the world faced crucial changes and transformations in the perspective of the perception of sovereign state position and great power eminence. The position of sovereignty for a state means the struggle for its citizens' rights, economic welfares and its fair governance. But, in spite of these changes and transformations, Russian leaders and policymakers have tried to maintain Russia's position as a sovereign state and great power in the international system in the mind of the 19th century's absolutist approach. Concurrently, these attitudes and behaviours of the leaders and policymakers have comprised a basis for Russiathe West conflict including China as a third party today. Russia puts forward absolutist regimes as its preference in the perception of its $21^{\text {st }}$ century's sovereign state and great power with its foreign policy applications and discourses. In this context, the aim of the article is to analyse Russia's foreign and security policies in the Balkans by underlining its assertive great power and absolutist regime approaches.
\end{abstract}

\author{
Keywords \\ Russia \\ The Balkans \\ Sovereign State \\ Great Power \\ Makale Hakkında \\ Geliş Tarihi: 28.06.2021 \\ Kabul Tarihi: 15.12.2021 \\ Doi: $10.18026 /$ cbayarsos. 958578
}

\section{Rusya'nın Büyük Güç ve Egemen Devlet Algısının Balkanlar Üzerine Etkileri}

\section{Özet}

Devletler, 20. yüzyılın sonlarında uluslararası sistemde egemen devlet ve büyük güç algısı açısından önemli değişim ve dönüşüm yaşamışlardır. Devlet için egemenlik durumu vatandaşların haklarının korunması, ekonomik refahlarının arttırılması ve kendisinin adil yönetimi anlamını taşımaktadır. Ancak söz konusu değişim ve dönüşüme rağmen Rus liderler ve karar alıcılar, Rusya'nın egemen devlet pozisyonunu ve büyük güç algısını uluslararası sistemde 19. yüzyılın mutlakiyetçi yaklaşımı ile korumaya çalışmaktadırlar. Rus liderlerin ve karar alıcıların bu davranışları ve tutumları aynı zamanda Çin'in de üçüncü taraf olarak yer aldığı Rusya-Batı çatışmasına temel oluşturmaktadır. Rusya, 21. yüzyıl egemen devlet ve büyük güç algısında mutlakiyetçi anlayışı tercih ettiğini dış politika söylemleri ve uygulamaları ile ortaya koymaktadır. Bu bağlamda çalışmanın amacı, Rusya'nın Balkanlara yönelik dış ve güvenlik politikalarını egemen devlet ve büyük güç algısı çerçevesinde analiz etmektir.
Anahtar Kelimeler

Rusya

Balkanlar

Egemen Devlet

Büyük Güç

About Article

Received: 28.06 .2021

Accepted: 15.12 .2021

Doi: $10.18026 /$ cbayarsos. 958578 


\section{Introduction}

The end of the $20^{\text {th }}$ century presented a meaning change for "sovereign state" and "great power" concepts in the international system. The meaning of the concepts grew away from military power understanding and started to focus on states' ability, mentality and power on the protection of their citizens' human rights and economic welfare, and on the sustainability of fair governance. All states in the international system realized the changings and transformations in these concepts and gained a new perspective on sovereign statehood and being great power. But, this development created a conflict between Russia and the West in the context of their leadership and authority perceptions in the international system. The conflict has still feeded into the $21^{\text {st }}$ century's international order. Russia has choosen the $19^{\text {th }}$ century's absolutist approach about sovereignty and great power eminence while the West has focused on liberalism, fair governance and human rights. Russia has tried to maintain military power perception on the mind of sovereignty and great power status but it is clear that there is an international status hierarchy as a part of the global hegemony. In spite of Russia's arbiter role in the global hegemony, it has not hinder the changings as in the Cold War. From the beginning of the Cold War, the Western great powers promoted liberalism economically and politically, and the Soviet Union could not intervene in the Western assaults and the emergence of global liberalism. The concepts such as democracy, fair governance, human rights and free market standard started to gain an importance. Moreover, the dissolution of the Union of Soviet Socialist Republics (USSR) lead to inaugurate global liberalism.

Russia has still tried not to admit the new meaning and content of great power status and sovereignty since 1996. The post-Soviet leaders have struggled for constructing and covering great power status and sovereignty perception in the context of military capabilities. They have tried to restrain the softening and flexibility of sovereignty provided by liberal humane and economic values. "Russian observers emphasize the destabilizing effects of these changes, and they are especially concerned about the eroding power and authority of nation-states, which they still regard as the ultimate guarantor of stability and order, both domestically and internationally"(Krickovic and Weber, 2018: 296-297). "There has been a common belif among Russian leaders, scholars and experts that there is a need for a multipolar order and $21^{\text {st }}$ century 'Great Power Concert' to manage the complexities of today's world" (Lukyanov, 2014). The main emphasis is that there must be a hard Westphalian understanding and notion of sovereignty, great powers must be free in their internal affairs and share their powers to each other. On the other hand, Russia has constructed monolithic and vast security and statebuilding instruments to promote and support sovereignty and great power eminence in its internal structure. Statist patriotism has also been raised in Russia by the governance in a historical background perspective. "All efforts supporting Russia's great power eminence and internal sovereignty are based on Russia's old European values and far from the new, inherent, humanistic and independent values of the West" (Makarychev, 2018). In contrast, Russia has still tried to preserve its great power eminence and sovereign statehood in military power and armed intervetion understanding and usage. Although the security order and international system after the post-Cold War underline sovereign nations, democracy and individualist values, Russia justifies its absorbition of Crimea and armed intervention in Ukraine as the must of great power eminence and sovereign-statehood. Moreover, this approach's imprints have clearly seen on Russia's security perception and policy. Russian leaders and officials have 
tried to construct a security policy focused on economic, political and institutional structure in the context of its great power eminence and sovereignty approach. The main aim is to make Russia strong again domestically and internationally. These main themes have been placed in Russia's 2009 and 2015 National Security Strategies. Russia has implemented this security strategy since the beginning of the Cold War. In fact, the core of the security policy has not changed apart from the tools up to the present. The main issue is to maintain great power eminence and sovereignty sagely and dominantly. One of the regions affected by Russia's security policy oriented in its great power and sovereign-statehood eminences is the Balkans.

The Balkans have been in the agenda of Russian foreign policy since the war between Ottoman Empire and Tsarist Russia (1877-1878). Moreover, Russia paid more attention to the Balkans in the periods of the Soviet Communist regime and the eruption of the Second World War. Espacially, Soviet military forces struggled for the establishment of Communist regimes in the countries on the Balkan Peninsula (Southeastern Europe) after the Second World War. Ultimately, communist regimes took place in many countries in the Balkans throughout the Cold War. In general, Russia became successive in constructing communist regimes except for Turkey and Greece. Turkey as alliance of the United States succeeded to keep away from the spreading effect of communism. In any case, both countries took part in the North Atlantic Treaty Organization (NATO) in 1952. Hardly, the adventure of the USSR'scommunism started to thow by Yugoslavia's and Albania's leaving the Soviet bloc.

Some Balkan countries (Albania and Bulgaria) took part in the Soviet bloc and Warsaw Pact until 1991. The end of the Cold War and the breaking up of the USSR as a milestoneled to emerge a change for the relations between Russia and the Balkans. In this context, it is possible to say that Russian foreign policy has focused on the Balkans. Besides, Russia has revised its national security strategies by considering its foreign policy, great power eminence and sovereignty. This article aims to explain and discuss how Russia's great power eminence and security politics affect its behaviours and attitudes related to the Balkans. The article first sheds light on the importance and dynamics of Russia's great power eminence perception and sovereign statehood in the context of its $21^{\text {st }}$ century and post-Cold War security understanding. Then, it focused on analyzing Russia's national security strategies and foreign policy their effects on the Balkans.

\section{The Dynamics of Russia's Great Power Eminence and Sovereign Statehood: The Nexus with Security Notion}

The collapse of the USSR enforced Russia concede its superpower eminence. "This event embarrassed Russian leadership who then retooled Russia's instruments of national power and redefined how Russia engaged globally" (Gallagher, 2020). Russia endeavoured during the 1990's economically, politically and militarily in its internal structure and international system. Russia tried to regain its superpower eminence as in the Cold War against the United States as the sole superpower in the world. "In the early 2000's Russia began to get back on its feet showing early aspirations of returning to great power status as evidenced by systematically retooling and bolstering its instruments of national power (diplomacy, information, military or economic)" (Gallagher, 2020). Moreover, Russia's annexation Crimea in 2014 led to reexplain the contemporary security environment. But, 2020 showed a new and 
unanticipated problem to the contemporary security environment named as COVID-19 by courtesy of other countries' unpreparedness.

Gallegher (2020) and Neumann (2008) state that if a sovereign state is perceived as having the capacity and specialist to employ its political, economic and military strengths and influences on a global scale, it is identified as 'Great Power'. As it is known, Russia was disconcerted by the breaking down of the USSR and this event was perceieved as the sterling geopolitical disaster of the $20^{\text {th }}$ century. Looking back, Russia's great power eminence has derived from its past. "From early contacts between Muscovy and the Holy Roman Empire through the rapid increase in contact during and following Peter the Great's reign and finally during the Soviet period, Russia has tried to be recognized by the leading European powers as their equal" (Neumann, 2008: 128).

In the early 1990s, both Russian politicians and citizens never admitted European politicians' views on Russia as a small-power. Russia must be a great power or it wil face with the end in the world history. In those years, the general view was that if Russia does not gain power again, it will live as an Asiatic state. In general, "the quest for recognition as a great power has been both the result of Russia's geographic expansion and its driver" (Gurganus and Rumer, 2019). Geographic expansion emphasizes the centre of Russia's claims to recognition as a great power. Besides, great power eminence constitutes the centre for Russia's security perception and a responsibility for its strategies and approaches in high-valued subjects such as the controls of nuclear arms, NATO's expansion and wars in Syria and Ukraine. Great power eminence has an effect as a catalytic for Russia's national identity. Great power eminence means a sovereign state internally and a great power externally in the context of Russia's 'in-out' politics. In Russia's national security logic, great power eminence stands at the midpoint of Russian political life. The eminence mentioned is strengthened by social power and potency. Great power and sovereign state eminences need more over the political entities and duties in the international system for international peace and security. To gain a certain eminence and a rightful identity necessitate social standards in the perspective of international and national societies. Because of this reason, status conflicts include states, socities and leaders.

The USSR in the late 1970s till the 1990s was perceived as a failing state. Besides, Putin's Russia was viewed as failing one. "The Soviet polity and society that languished during the second half of the Brezhnev regime and the successor interregnum of Andropov and Chernenko were characterized as in the period zastoya by perestroika-period officials and observers" (Willerton et al., 2005: 224). In other words, the officials in Gorbachev period were aware of a deepening state legitimacy crisis and a potential state failure in spite of the logic for perestroika. As a result, "embedded autonomy which is precisely the mirror image of the incoherent despotism of the predatory state, is the key to the developmental state's effectiveness" (Evans, 1995: 50). It is also clear that the state could not meet the societal demands. The same developments, reflections and views also took place in the first step of Putin's Russia. "When Putin was put in charge of the Russian government, he faced an equally daunting task of regenerating a failing state caught in difficult economic and political conditions" (Willerton et al., 2005: 225). On the other hand, "The Yeltsin regime had overseen Russia's transformation from a command economy and authoritarian political system to a 
fledgling democratic polity with a regulated market, but the forces of corruption and decentralization overwhelmed much of the country's economic and political reality" (Willerton et al., 2005: 225). In spite of all efforts by Russian elites since 1980s for Russia's reigning status hierarchy, Russia was not perceived as a great power in the context of international security. Besides, Russia was exposed to criticisms on sovereign statehood.

The claims on sovereign statehood focus on the social standards that Russia presents and are related to satisfaction level internationally. All Russian leaders and elites have tried to change its eminence since post-Cold War for its $21^{\text {st }}$ century projection in international system and security. For the majority of Russian leaders and elites, eminence and security are interrelated to each other and undistinguishable. Putin emphasizes the relation between eminence and security in his manifesto. "One of Putin's main points in his manifesto was that throughout history, the Russian state lost its status when its people were divided, when Russians lost sight of the common values that united them and distinguished them from all others" (Hill and Gaddy, 2013: 36). Putin has also put forward that Russians have held the rights and freedoms on personal expression, travelling abroad and free market since the collapse of communism. He has also mentioned that there are universal values but they are not Russian and enough to assure Russia's survival. Putin has mainly highlighted Russia's own values as "patriotism, collectivism, solidarity, derzhavnost' - the belief that Russia is destined always to be a great power (derzhava) exerting its influence abroad - and the untranslatable gosudarstvennichestvo" (Hill and Gaddy, 2013: 36). In short, the main elements for Russia's secure in the $21^{\text {st }}$ century are great power eminence, sovereignty and economical progression. This necessitates following security by eminence-politics. In this context, Russian society's subordination to the state is the major factor for Russia's sovereignty as a state. It can also be said that the understanding of sovereignty an democracy of the West and Russia are different of each other. While the West focuses on promoting liberalism, democracy and civil society, Russia has prioritised the 'state' by ignoring society, individuals or social forces.

For Russia, to be a sovereign state and great power requires economical progression based on industrial and high-tech economy. Putin, in his first speech as a prime minister, declared that Russia needs an urgent transformation aconomically and investments for high-tech economy to be a great power in international order. Besides, it was emphasized that Russia needs engaging global economy and finacial systems. Economical progression will provide Russia to sustaining and reinforcing sovereign statehood and great power eminence. For this purpose, Putin has tried to keep economic liberals in eminent positions (Laruelle, 2017). In the logic of Russia's leadership, as a sovereign globalization concept mainly takes place and Russia has a restricted interdependence in the context of global economy. On the contrary, Europe and other many regions need Russian oil and gas, so Russia tries to use their dependence as an advantage aconomically and politically.

By high oil prices and domestic production, Russia had vigorious growth and its economy had grown rapidly from 1998 oil price crisis till 2011 (Popova et al., 2017: 15-16). Ultimately, Russia was the sixth economy in the world (Rasoulinezhad, 2016: 73-75). The growth of economy provided Russians to reviving and remembering their country's international eminence. Also, Russian society gained a chance to envisage the great power eminence of Russia and Putin's administration gained trust to employ its great power eminence with force as in Georgia, 
Ukraine and Syria. As a result, Putin has tried to change the general perception which only focuses on great power eminence and sovereignty provided by military power on the contrary to previous leaders and Russian policy elites. He has emphasized the necessity of economic transformation through high domestic production with high-tech and the capacity of competition (Aris and Tkachev, 2019).

For both Russia and Soviet state, great power eminence and sovereignty are the main elements in the perspective of state's survival and future projection. In this context, there is a mutual relation between national security and the perception of great power eminence and sovereignty. The perception of great power and sovereignty provides Russia to struggling against foreign support for internal protests and other great power's interventions. Especially, the eminence is the main tool for consolidating Russians and keeping internal distress. Reconstructing sovereign statehood position is the main road for leaders to national security strategy. Putin, in his 1999 Millennium speech, emphasized the importance and necessity of traditional statism for the country's survival and citizens (Aridici, 2014). He has also tried to develop state-centered nationalism in the basis of sovereign democracy in the country over the past decade. The traditional approach of nationalism and statism has provided Russia to constructing easily the perception of great power eminence and sovereignty as a state in the context of loyalty to the state (Hill, 2016). In general, it has supported populism, ethnocentric nationalism and mistrust of states in the West to substitute the liberalisng global elites in the context of its absolutist approach of sovereign statehood.

In the structure of Russia's statism approach, non-state actors, human rights and democracy proponents, and non-governmental organizations are generally perceived as potential threats in the axis of sovereign statehood in the country, great power eminence in the international system and the sovereign-state system (Kasymov, 2012: 60-61; Barham-Marsh, 2018). Russia has also felt democratic protests and activisim worldwide as a threat. To offset the dangers or whether the threats, Russia, as in the past, has employed its armed forces and tried to increase its military capacity because it believes that great power eminence and sovereignty depend on military tools only.

Concordantly, Russia set forth some assults and intervention on the behalf of its great power eminence and sovereign statehood. At first, Russia used armed force during the Kosovo crisis as a response to the West's intervention for reminding its great power eminence (Antonenko, 2007: 5-6; Levitin, 2010: 134-138). In Russia's this assult, one of the main aims was to prove its historical, protective and dominative role on the Slavs and southeastern Europe in general by taking its hinterland mind into consideration and the second one was at the attempt of Chechens' independence for the exhibition of Russia's sovereign statehood (Brudenell, 2008: 32-34; Baranovsky, 2008: 115-118).

As mentioned, Russia has tried to take advantage of many internal and external developments for propounding its great power eminence and sovereign statehood, and it has reflected all those struggles in its security strategy and military modernization. Russia's this approach has clearly been realized in its counterterrorism after 9/11 and muslim terrorists towards Russia in the axis of its security strategy and using armed force. In brief, the lack of perception of Russia's great power eminence and sovereignty has led Russia to using armed force since the 
post-Cold War and to improve and revise its military power and security strategy. Besides, Russia has still assumed the Balkans, Central Asia and Caucasus as its hinterland, and it has extended its security zone up to these regions in the context of its national security strategy. The Balkans as one of the regions has eventfully taken place in Russian foreign policy and security strategy (Antonenko, 2007: 7-8).

\section{Russia's Influence on the Balkans within the Scope of Foreign and Security Policies}

For Russia, the Balkans have mattered and took part in Russian foreign policy since the 1870s (the defeat of Ottoman Empire). At the time of WWI and WWII, Russia never blow cold for the Balkans and tried to impower the ties through the Comintern. After WWII, the Soviet Communist regime took place in Yugoslavia, Bulgaria, Romania, Albania and the Soviet Union gained power in the region. In the early 1950s, both the Soviet bloc and Warsaw Pact started to crack through Yugoslavia's leaving at first. The end of the Cold War and the breaking up of the Soviet Union led to alter Russia's position in the Balkans and led Russia to revising its Balkans policy within the scope of its foreign and security policies.

As in the past, Russia has today struggled for holding its historic, cultural and religious ties with the Balkans. Therefore, Russia progressively asseverates itself in the region by trying to decelerate the Balkans' integration to Euro-Atlantic and keeping away from the region countries from the Western democracy approach. Moscow has focused on cultural ties and commercial integration with the Balkans. In this context, the Kremlin has particularly deepened the "economic and trade relations in many sectors such as energy, banking, real estate and communication technology for increasing the dependence of the region countries" (Stronski and Himes, 2019). "Russian influence operations foster people-to-people connections, with the goal of creating Russian-friendly local constituencies and levers of influence that could allow Moscow to inhibit further integration into Western economic, political, or security structures"' (Stronski and Himes, 2019).

For the Kremlin, the Balkans has geostrategic location because the region constitutes a triangle and bridge among the Black Sea, the Mediterranean Sea and the Middle East. Russia has tried to use the region as a tool for restraining EU or NATO enlargement. "The Kremlin's influence campaign in the Balkans also helps steer Western focus away from more disturbing actions elsewhere-Russia's military buildup in the Sea of Azov and subsequent aggression in the Kerch Strait, the worsening war conditions in eastern Ukraine, South Ossetia's moving boundary line, and Moscow's subtle influence operations targeting post-Velvet Revolution Armenia" (Stronski and Himes, 2019). In the region, Russia has struggled for a competetion with the West, NATO, China, Turkey, and even Persian Gulf states. For the competition and inflence, Russia has not produced more except for energy to the region in consideration of the competitors' different tools and approaches. It is clearly seen that Russia needs more tools for holding the miscellaneous ties with the Balkans. On the other hand, using hard power accasionally, such as in the annexation of Crimea and war in eastern Ukraine led to undermine Russia's soft power efforts. But, today Russia has not renounced from the Balkans no matter as in the past. In this regard, Russia has constructed its foreign and security policies in the axis of its great power eminence and sovereign statehood. 
Russia has an uneven foreign policy historically. After the breaking up of the Soviet Union, Russia took part in the international system as an independent state again in December 1991. "Ideas about democracy, the market, self-determination, and integration with the Western capitalist system eventually crystallized during the peak of polarized confrontation in 1990-91 as concepts most clearly antithetical to the Soviet ancien regime." (Mcfaul, 1999). When Yeltsin was elected as the president of Russia in June 1991, he and his government declared to advocate liberal ideas as pro-Western idealists. In other words, they highlighted the loyalty of Western values and integration. "His foreign policy is fundamentally flawed in that, rather than being based on concrete national interests, it is basically a negative reaction to the former Soviet Union's foreign policy based on the personal whims of the President and his Foreign Minister and a desire to break with the former Soviet Union's allies and friends and befriend its enemies" (El-Doufani, 1999: 106).

In spite of liberal ideals and the approach of the integration into the West, Russia tried to maintain the great power eminence and sovereign statehood in domestic and foreign policies. Although economic oligarches, business lobbies and people demanded to accelerate the integration into the West, Russia focused on avoiding submissiveness to the West in the perspective of great power eminence and maintaining its absolutist structure.

In brief, Russian foreign policy was dominated by pro-Western idealists after the breaking up of the Soviet Union. In this context, Andrei Kozyrev was a pioneer for promoting Russian integration into the West and engaging Western assistance for Russia's economic and political transformation internally. But, liberal ideals were broken by the parliamentary election in 1995. The Communist Party of the Russian Federation won the election and Yeltsin enstated Yevgeny Primakov as the foreign minister. By courtesy of Primakov and NATO expansion, Russian foreign policy took part in a major challange during this period. Besides, 1998 financial cirisis caused a structural change as the transformation of the foreign policy from pro-Western pragmatism to anti-Western pragmatism.

In terms of national security in Yeltsin period, Russia failed to construct an effectual system to organize and incorporate national security policy. It is clear that special interest groups, oligarches and bureaucratic actors had an effectice role on decisionmaking of national security and foreign policies. Moreover, the institutional weaknesses caused confusion and incoherence internally. At his first, perios, Yeltsin was not able construct a long-lasting institutionalized structure for national security policy. The "lack of clear institutional lines of authority and overarching mechanisms to coordinate defense policy meant that defense policy often became a contest among rival factions who sought to appeal directly to Yeltsin over the heads of other bureaucratic actors" (Larrabee and Karasik, 1997).

It is possible to say that Yeltsin tried to construct a framework for Russia's national security and foreign policies institutionally through many legal documents by taking its great power eminence and sovereign statehood internally and externally into consideration. One of them was 'the Foreign Policy Concept of the Russian Federation' which explained the priorities of Russian foreign policy after the Cold War in international system. The document foxused on the reestablishment of bilateral relations with the Balkan countries such as Albenia, Bulgaria and Romania. The second one was 'the Basic Propositions of the Military Doctrine of the 
Russian Federation' which mostly laid out Russia's approaches to the military conflicts in the Balkans. Yeltsin affirmed the draft of 'National Security Concept' that explained Russia's interests in the context of its national security and foreign policies through the developing multipolar world. The draft document also emphasized the geopolitical and geostrategic importance of the Balkans in terms of Russia's national security and foreign policies. Again, Russia highlighted its great power eminence and sovereign statehood in this document. In brief, Russia tried to get under control the Balkans for its national interest in its great power eminence and sovereign statehood through its national security and foreign policies, and its historical ties derived from the Soviet Union.

Vladimir Putin as Yeltsin's succeeding took the chair of the Russian Federation Prime Minister in 1999. Then, he was the president of the Russian Federation on 26 March 2000. He has still in power for 21 years. "Nonetheless, it is clear that the Putin era is drawing to a close and an attempt to make sense of what has (and has not) been achieved over the last 20 years is not only useful, but necessary in view of the inevitable changes that await Russia in the future" (Trenin, 2019). Although Russian foreign policy during Putin's era can be interpreted and avaluated in different perspectives, it is clearly seen that Putin has two main aims as protecting Russia's unity and restoring and pursuing Russia's great power eminence in the international system. In Putin's era, the vertical shape of power has been formed in an imperious structure. "The political regime that replaced the chaos of the 1990s has been unable to mature into a full-fledged state: it predominantly services the needs of a narrow elite, who are exploiting the country's resources for their personal and collective aims" (Trenin, 2019). The inheritance of foreign policy in Putin's era is comprehensive, diverse and assertive. All these characteristics have led Russian foreign policy maintaining and pursuing to its changing structure. "Back in 2000 Putin was actively calling for Russian membership in NATO; in 2001, attempting to become the United States' most important ally, he gave orders to provide any assistance and support to American troops in Afghanistan; building a Greater Europe that would stretch from Lisbon to Vladivostok, Putin not only gave a speech in the Bundestag in German in which he proclaimed Russia's European choice, but emphatically encouraged the exchange of capital assets for the creation of a common economic space" (Trenin, 2019).

Putin's foreign policy, for sure, has successes and failures as in general. The successes can be summarized about as below:

- Restoring Russia's sovereign statehood. The fast increase of oil prices in the 2000s caused Russia's economic growth and leaving external financial dependence.

- Constructing a national energy policy. In the context of energy security, the reforms in Russian armed forces provided the Kremlin preserving and promoting the country's national interests and defense.

- Reclaming itself as a great power. Russia, in a military and political concept, redefined itself as a great power in the international system by declaring its political, military and aconomic power and its defending capacity ignoring outside help.

- Constructing expanding relations from EU to Southeast Asia. Putin has tried to develop the relations from West to East. Moscow has especially focused on expanding its position in the east of the country. For this purpose, Russia has tried 
to construct close relations with India, Japan and ASEAN countries including strategic partner China. Besides, bilateral and multilateral relations as part of the Shangai Cooperation Organization, BRICS and RIC have led Russia to keeping and pursuing balance with the more vigorous and improved countries.

- Presenting the dynamic balance of Russian foreign policy. Moscow showed its foreign policy's dynamic balance with the operations in Syria. Here Russia tried to reveal its unique position and the capacity for maintaining effective relations with the forces and the countries in the region.

On the other hand, the failures are as below:

- Unable to implement the nationalization of the elite. Russian elite has still far away from the national interests.

- Putin's managirial team has mostly dealt with materialistic values and they have not employed to the duties state service themselves.

- The lack of perception and cooperation on a Greater Eurasia.

- A roller coaster in the cooperation with EU.

- The stable obsession on NATO expansion.

- The lack of economic integration with CIS, BRICS and ASEAN countries.

In brief, it is not possible to say that Putin's ambitions have failed to stand the test of time yet. Russia, of course, has looked with favour on the multipolar world idea. The main aim is to construct a geopolitical and geoeconomic balance in the international system. On the other hand, Putin's efforts to changing current global order have occasinally damaged to Russia's image domestically and externally. Moreover, in spite of Putin's statements that Russia will not allow to a confrontation with the U.S., two countries have approximately been in a confrontation for 7 years. It is clearly seen that Russia should analyse and revise its foreign policy periodically.

The national security under Putin has differed from Yeltsin's. There are two main reasons for this difference. "First, the composition of Putin's domestic, political, and economic coalition is unlike that of Yeltsin's, and, secondly, that Putin is dealing with an economy driven by rising energy prices. Putin is now in a position to defy the oligarches' control over the country. The strength of the economy lies in capitalizing on advanced technologies and exporting competitive sectors of the defense industries" (Crabtree, 2000). On the other hand, Russia's these interests have been neglected in criticising Russia's international role by the West. Since 2000, Putin has struggled for national security against the threats that are analyzed by taking Russia's national values, interests, and goals into consideration.

Putin's national security policy is based on the purpose of returning to the Russian Federation the status of world power. At first, Putin tried to transform the 'idea of Russia' in the 2000s. "The new National Security Strategy brings discussion to its logical conclusion by offering a definition of Russia's 'traditional spiritual values' and suggesting that these values are specifically Russian and formulated in contrast to Western humanitarian values" (Pynnöniemi, 2018: 243). It is clearly seen that the definitions of 'national interest' and 'threats to national security' are the key terms in the strategy documents of 2009 and 2015. Besides, the strategy 2015 includes two new terms - 'independence' and 'state integrity' - in the definition of 
'national security'. "The four key terms of this definition - namely, sovereignty, independence, and the state and territorial integrity (целостность) are separate yet inextricably linked terms" (Pynnöniemi, 2018: 246). The Kremlin has also highlighted the concept of sovereignty as the base for Russia's strategic mind. Here real sovereignty means that the country is not dependent on other countries by its alliances or political, military, economic and technological interdependencies. The Kremlin again emphasizes Russia's great power eminence and sovereign statehood. "According to the strategy documents, the Kremlin has stated the main tasks for assuring the Russia Federation's national security by taking Russia's great power status and sovereign statehood into consideration as followed" (Arms Control Association):

- to promptly detect and identify external and internal threats to national security;

- to take short- and long-term action to avert and remove internal and external threats;

- to ensure the sovereignty and territorial integrity of the Russian Federation and the security of its border lands;

- to improve the economy and pursue an independent and socially-oriented economic policy;

- to overcome the Russian Federation's scientific and technological dependence on external sources;

- to ensure citizens' personal security and constitutional rights and freedoms in Russia;

- to improve the system of state power in the Russian Federation, the system of federal relations and local self-government and legislation; to create harmonious relations between communities, and to strengthen law and order and preserve socio-political stability in society;

- to ensure unwavering compliance with Russian Federation legislation by all citizens and officials, state bodies, political parties and public and religious organizations;

- to ensure Russia's cooperation, especially with the world's leading countries, on equal and mutually advantageous terms;

- to increase the state's military potential and maintaining it at a sufficient level;

- to strengthening the regime of nonproliferation of mass destruction weapons and their delivery vehicles;

- to take effective action to identify, avert and intercept intelligence and subversive activities by foreign states against the Russian Federation;

- to fundamentally improve the country's ecological situation.

- It is an important priority of state policy to ensure national interests and uphold the country's economic interests.

It is clear that Russia as in the past has still preserved its great power eminence perception and sovereign statehood in the construction of its foreign and national security policies. Besides, it seen that the Kremlin will not give up these approaches in the future in the context of multipolar world and the changing international system. 


\section{The Balkans in Russian Foreign and Security Policies}

Russia in the Balkans has indispensible, deep and historical ties. Russia's foreign policy has experienced many vital changes since the 1990s. The reasons of these changes have mostly derived from external factors. The Balkans moved away from the periphery of Russia's foreign military, political and economic interests. Russia tried to close to EU and the U.S. in that period. In some way, Russia shelved the Balkans for a while. In the first half of the 2000s, Russia had a pragmatic cooperation with EU and took place in the Balkans through economic diplomacy. In those years, Russia had a perception based on that the Balkans had not only economic ties but also political and cultural ties as in the past by emphasizing the Soviet Union. However, the increase of the contradictions between Russia and EU in the second half of the 2000s led Russia and EU to moving military and political issues into the foreground (RIAC). At a stroke, the Balkans such as Baltics, Central Europe and Southeast Europe turned to a conflict area of interests.

As it's known, Russia revised its foreign policy and reevaluated its reconciliation with the West in the 1990s. The major factor was the Yogoslav crisis in this process. One of the most important steps in this process was the recognition of the new republics by Russia. Russia supported the sovereign statehood of the new republics. "By frozing its economic, political and cultural connections with the Socialist Federal Republic of Yugoslavia, Russia attended the implementation of Resolution No. 757 of the UN security Council" (RIAC). In spite of the reconciliations with the West, Russia had contraversial decisions with the West about the sanctions against Yugoslavia through its new foreign policy. The other important step of Russia was its participation in the Dayton and Paris Peace agreements. It can be inferred from the process that Russia has eagerly supported "the stability and territorial integrity of Bosnia and Herzegovina for over 30 years" (RIAC). However, Russia yewied above the Atlantic. The main reason was "the crisis around the Socialist Federal Republic of Yugoslavia and NATO's bombings" (RIAC). So, Russia sufferred from the international and unilateral approaches.

Russia's foreign policy focused on the perception of EU as a prosperous integration union during the first half of the 2000s. Russia kept itself out of the handling of regional security issues except for Kosovo and Bosnia and Herzegovina cooperations. As a result of Russia's putting ephasis on economic diplomacy, LUKOIL firstly placed in many regions of the Balkans in 1998-2007 and the number of Russian investors increased rapidly in the Balkans in 20042006. The other Russian companies such as Zarubezhneft, Gazprom and Sberbank occupied an important position in the region.

Russia tried to take part in the Balkans through economic and infrastructure projects by the early 2010s. The main aim was to enlarge and empower economic presence in the region. But, Russia failed to transform its economic presence to political influence against the expansion of the EU. On the other hand, Russia went against the roots and dynamics of its foreign and national security policies. Moscow reflected unilateral approach (economic dimension) to the Balkans within this period. In fact, this one-way approach has contradicted to Russia's great power eminence and sovereign statehood. In other words, the perception of Russia in the Balkans has mostly dealt with economic perspective by being far away from political, cultural, security and technological dimensions. Thus, Russia failed to create a 'great power' perception in the Balkans. 
There was a conjectural encounter between Russia and the West in the Balkans by means of stultifying of the South Stream project. "Since February 2014, Brussels has been inclined to view the Balkans as a foothold for potential aggression on the part of Russia, an area of mediated confrontation, an objective geographic buffer that protects Europe against the Russian threat" (RIAC). The combative behaviours and attitudes of Brussels have led to Russian companies' operations to coming to a stop and created political crisis in the Balkans. The struggles of the West's strategical deployment in the Balkans has increased Russia's 'Balkans' desires in not only economic but also political, security, cultural and technological perspectives. Russia has employed its new strategy of the Balkans through the lessons from the developments since 2018 in the context of its renewed foreign and security policies. There are some key factors influencing Russia's foreign and security policies in the Balkans. The key factors for foreign policy are: - the EU's objective difficulties in the Balkans, - traditional symphatheticisim of the Orthodox people in the Balkans to Russia, - the increase of Russia's political successes such as the military operations in Syria, the role in the creation of Euasian Economic Union and the role in constructing special tools for connection with Turkey, Iran, China, the BRICS and CIS countries. Besides, NATO's enlargement and military deployments of the U.S. in Albania and Greece have taken place in the main key factors for Russia's security policy.

From past to present, Russia has tried to exist for maintaining its influence in the Balkans through different approaches and argumentums. The important one was its natural gas supplier role in the Balkans. But, that prospect exiled since 2014. By virtue of Russia's annexation of Crimea in the early 2014, the transit route of Russian natural gas along southern Ukraine decreased (Pirani, 2018: 4). Besides, Bulgaria's explanation on taking part in 'South Stream' project caused a disappointment for Russia and its plans about energy shipments to the Balkans. On the other hand, Russia has realized that even if 'South Stream' and 'Turkish Stream' pipelines come on line, the capacity of the two lines are not enough as its line in southern Ukraine. It is likely foreseen that most of the Balkans will probably need Russian natural gas in spite of the lack of the two stream projects' capacity.

To maintain the influence in the Balkans, Russia has tried to make cooperations multilaterally. In this proces, Turkey has an important role but, as one of the allies of NATO, Turkey present a remittent approach in the relations with Russia as in Syria civil war and F-35 programme. Besides, Russia has an uneven relation with Greece as in the dispute between the Greek and Macadonian governments over Macedonia's name and Greece's ties with NATO and the EU.

In brief, Russia's foreign and security policies in the Balkans have produced miscellaneous results. Russia's struggles for maintaining influence in the Balkans in the context of its great power eminence and sovereign statehood have led an axis shift for Russia in the region. Besides, the mixed structure of the Balkans in economic, political, cultural, religious and historical perspectives has prevented Russia conducting stabile foreign and security policies. On the other hand, the essence of NATO, the EU and U.S. and external factors are the majors one negatively on this issue. However, Russia has struggled for maintaining its influence in the Balkans in spite of these negative factors. Russia's stubborn struggles for pursuing its influence in the Balkans in the context of its great power eminence and sovereign statehood have led the Balkans to taking part in a rivalry place and an uncertain future. 


\section{Conclusion}

The Balkans has an important role in Russia's foreign and security policies since the $16^{\text {th }}$ century. The region acted as the best way to reach the warm seas of the Mediterranean. Moreover, Russia took part in the Balkans ideologically through the socialist regimes in the region. In spite of Albania's and Yugoslavia's splitting with the Kremlin, the influence of the Soviet Union in the Balkans would remain till the end of the Cold War. However, Moscow's influence start to decline with the breaking up of the Soviet Union. Despite all Russia tried to maintain its great power eminence in the Balkans throughout the 1990s against 'Pax Americana' period started with the wars in Former Yugoslavia. Russia synchronously struggled for the long-termed problems derived from awkward structure of the Soviet Union. The start of the next millennium will present a chance to Russia for regaining its lost effects in the region.

Russia acidly prologuized to the millennium through Vladimir Putin. It handled to get over many internal and external problems. "Consolidation of Kremlin's power under Putin and economic advance of the 2000s and 2010s helped with the export of oil and gas, heightened Russia's foreign ambitions" (Muhasilović, 2020: 196). Putin's successes reflected to the Balkans as well in the perspective of energy powerhouse. Russia tried to construct political, economic, cultural, technological, etc. ties in the Balkans apart from its natural gas monopoly role in the region. Thus, it is possible to say that Russia has regained its lost influence. However, Russia's influence was shattered by its annexation of Crimea in 2014. With the start of the crisis in Ukraine Russia revised its foreign and security policies in the context of its great power eminence and sovereign statehood. In this period, one of the main aims of Russia was to construct an anti-NATO campaign and anti-EU sensibilities by taking these organizations' interventions to the Balkans. Russia's strategy has mostly formed through its reliance to the Orthodox-Slavic populations in the region and this strategy has still gone on today with other tools. Today, Putin's Russia as in the past has maintained to perceive the Balkans as its hinterland\&backyard and tried to take part in the region with not only its energy powerhouse role but also economic, political, cultural, religious, ethnical, technological, etc. argumentums in the context of its great power eminence and sovereign statehood. Russia seems that it will never renounce to disassociate from the Balkans. In brief, The effects of Russia's great power eminence, sovereign statehood, foreign and security policies have adversely pursued to create a tidal position for the Balkans. On the other hand, the Balkans maintains its dilemma position between the West and Russia.

\section{References}

Antonenko, O. (2007). Russia and The Deadlock over Kosovo. Ifri Russia/NIS Center. Retrieved from https://www.ifri.org/sites/default/files/atoms/files/ifri_kosovo_antonenko_ang_ july2007.pdf.

Aridici, N. (2014). How Vladimir Putin has changed the meaning of 'Russian'. The Conversation, 9 April. Retrieved from https://theconversation.com/how-vladimir-putin-has-changed-themeaning-of-russian-24928.

Aris, B. \& Tkachev, I. (2019). Long Read: 20 Years of Russia's Economy Under Putin, in Numbers. The Moscow Times, 19 August. Retrieved from https://www.themoscowtimes. com /2019 /08/ 19/long-read-russias-economy-under-putin-in-numbers-a66924. 
Arms Control Association, Russia's National Security Concept. Retrieved from https://www.armscontrol. org/act/2000-01/features/russias-national-security-concept.

Baranovsky, V. (2008). The Kosovo factor in Russia's foreign policy. Italian Journal of International Affairs, 35(2), 113-130.

Barham-Marsh, B. (2018). Russia's privatised military: a move away from Statism?. Global Risk Insght, 22 March. Retrieved from https://globalriskinsights.com/2018/03/russias-privatisedmilitary-move-away-statism/.

Brudenell, A. M. (2008). Russia's Role in the Kosovo Conflict of 1999. The RUSI Journal, 153(1), 30-34.

Crabtree, L. (2000). National Security and Foreign Policy Under Putin. Wilson Center. Retrieved from https://www.wilsoncenter.org/publication/national-security-and-foreign-policyunder-putin.

El-Doufani, M. M. (1999). Yeltsin's Foreign Policy - A Third-World Critique. The World Today, 49(6), 105-108.

Gallagher, S. E. (2020). Assessing Russia's Pursuit of Great Power. Real Clear Defence, 2 June. Retrieved from https://www.realcleardefense.com/articles/2020/06/02/assessing_russias _pursuit_of_great_power_115341.html.

Gurganus, J. \& Rumer, E. (2019). Russia's Global Ambitions in Perspective. Carnegie Endowment for International Peace, 20 February. Retrieved from https://carnegieendowment. org/ 2019/02/20/russia-s-global-ambitions-in-perspective-pub-78067.

Hill, F. (2016). Putin and the Kremlin are experts at reading the popular mood. And they were watching America. Brookings, 11 November. Retrieved from https://www.brookings.edu/ blog/order-from-chaos/2016/11/11/putin-and-the-kremlin-are-experts-at-reading-the popular-mood-and-they-were-watching-america/.

Hill, F. \& Gaddy, C. G. (2013). Mr. Putin Operative in the Kremlin. Washington, D.C.: The Brookings Institution Press.

Kasymov, S. (2012). Statism in Russia: The implications for US-Russian relations. Journal of Eurasian Studies, 3, 58-68.

Krickovic, A. \& Weber, Y. (2018). What can Russia teach us about change? Status-seeking as a catalyst for transformation in international politics. International Studies Review, 20(2), 292300 .

Larrabee, F. S. \& Karasik, T. W. (1997). Foreign and Security Policy Decisionmaking Under Yeltsin. RAND, Retrieved from https://www.rand.org/pubs/monograph_reports /MR831 . html.

Laruelle, M. (2017). Kremlin's ideological ecosystems: equilibrium and competition. PONARS policy memos, 14 November. Retrieved from https://www.ponarseurasia.org/new-policymemo-the-kremlin-s-ideological-ecosystems-equilibrium-and-competition-m-laruelle/.

Levitin, O. (2010). Inside Moscow's Kosovo muddle. Global Politics and Strategy, 42(1), 130-140. 
Lukyanov, F. (2014). What the World Needs is '19th Century Behavior. Russia in Global Affairs, 22 March. Retrieved from http://eng.globalaffairs.ru/redcol/What-the-world-needs-is-19thcentury-behavior-16513.

Makarychev, A. (2018). Europe in crisis: "old," "new," or incomplete?. PONARS policy memos, 9 March. Retrieved from https://www.ponarseurasia.org/europe-in-crisis-old-new-orincomplete/.

Mcfaul, M. (1999). What are Russian foreign policy objectives?. Carniege, 1 May. Retrieved from https://carnegieendowment.org/1999/05/01/what-are-russian-foreign-policy-objectivespub-424.

Muhasilović, J. (2020). Rival Power: Russia's Influence in Southeast Europe. Book Review, Dimitar Bechev, Journal of Balkan and Black Sea Studies, 3(5), 195-206.

Neumann, I. B. (2008). Russia as a great power, 1815-2007. Journal of International Relations and Development, 11, 128-151.

Pirani, S. (2018). The Decline and Fall of the Russia-Ukraine Gas Trade. Russian Analytical Digest, No.221, 1-6. Retrieved from https://www.research-collection.ethz.ch /bitstream / handle/20.500.11850/269440/RAD221.pdf?sequence=2\&isAllowed $=y$.

Popova, L., Jabalameli, F. \& Rasoulinezhad, E. (2017). Oil Price Shocks and Russia's Economic Growth: The Impacts and Policies for Overcoming Them. Journal of World Sociopolitical Studies, 1(1), 1-31.

Pynnöniemi, K. (2018). Russia's National Security Strategy: Analysis of Conceptual Evolution. The Journal of Slavic Military Studies, 31(2), 240-256.

Rasoulinezhad, E. (2016). Investigation of sanctions and oil price effects on the Iran-Russia trade by using the gravity model. Vestnik St Petersburg University, 5(2), 68-84.

RIAC (Russian International Affairs Council). Retrieved from https://russiancouncil.ru/en/ russia-balkans\#1.

Stronski, P. \& Himes, A. (2019). Russia's Game in the Balkans." Carneige, 06 February. Retrieved from https://carnegieendowment.org/2019/02/06/russia-s-game-in-balkans-pub78235.

Trenin, D. (2019). 20 Years of Vladimir Putin: How Russian Foreign Policy Has Changed. Carneige, 28 August. Retrieved from https://carnegie.ru/2019/08/28/20-years-of-vladimirputin-how-russian-foreign-policy-has-changed-pub-79742.

Willerton, J. P., Beznosov, M. \& Carrier, M. (2005). Addressing the challanges of Russia's 'failing state': the legacy of Gorbachev and the promise of Putin. Demokratisatsiya: The Journal of Post-Soviet Democratization, 13(2), 219-239. 